\title{
Place Matters: But Does Local Leadership?
}

\begin{abstract}
The arrival of New Labour into Government witnessed the prominent re-emergence of place onto the policy agenda. This heralded a range of area-based-initiatives designed to both tackle neighbourhood forms of deprivation and to re-establish a sense of identity and connection between individuals and their local community. In terms of place-making, effective and inclusive participation, representation and leadership were all identified as prerequisites for the creation of sustainable communities. But how important is local leadership and strategic vision within local public service organisations in achieving the desired place-making outcomes? This paper examines the extent to which local leadership and strategic vision represents a significant factor in promoting higher levels of satisfaction, belonging, cohesion and participation across single tier councils in England. The ensuing empirical evidence raises significant questions not only about the importance of local leadership in place-making, but also the environmental and organizational factors that shape local places.
\end{abstract}

Dr. James Hunter, Principal Lecturer in Public Policy, School of Social Sciences, Nottingham Trent University, Nottingham, NG1 4BU email: james.hunter@ntu.ac.uk

Word count: 5729 (including abstract and references)

No part of this paper may be reproduced in any format without prior permission of the author. 


\section{Introduction}

New Labour consistently reasserted the importance of place in shaping the quality of life and opportunities within local communities (SEU, 2001; DCLG, 2008a). Seeking a more emboldened conception and understanding of place, official policy discourses emphasised the importance of strategic place-making and community participation (e.g. ODPM, 2003; DCLG, 2008b, DCLG, 2009a). A key feature of New Labour's model of local governance was an emphasis upon the importance of good local leadership and strategic vision (e.g. DTLR, 2001; DCLG, 2006). "The quality of leadership is central to success in addressing local challenges... The challenges identified by Total Place will require all public leaders to take a broader view of the leadership task in public services. Future leaders will not only be people who can work across organisations on behalf of their places, but people who engage effectively with peers, communities, the third sector and with local democratic representatives" (HM Treasury/DCLG, 2010:59). The emphasis for local councils was now upon a form of local leadership that was democratic, delivered through partnership, and community driven (Audit Commission, 2003). Local authorities were encouraged to drive forward community leadership (Stoker, 2004), and to exude a new level of confidence:

The powers and freedoms which local government can exercise are an important part of enabling councils to play this [place shaping] role. However, I am clear that effective placeshaping is as much about the confidence and behaviours of local government as it is about statutory powers or responsibilities." (Lyons Inquiry into Local Government, 2007: 174)

But does local leadership actually result in place-making that makes a difference in terms of the outcomes experienced by local citizens? Whilst existing research points to the importance of local leadership in shaping specific localities (e.g. Sweeting et al, 2004; Barber \& Eastaway, 2010; Collinge \& Gibney, 2010; Mullins and van Bortel, 2010), little empirical evidence exists on spatial variations in place-making outcomes, and the role that local leadership plays in creating communities that are characterised by a strong sense of identity and belonging. The aim of this paper is to provide an empirical test of the impact of local leadership upon place-shaping across local authorities in England. Capturing the dynamics and nature of local leadership on an individual basis is however fraught with methodological and practical problems. The aspect of local leadership that the analysis presented here therefore seeks to examine is the corporate leadership of local councils in terms of their strategic vision and capacity to facilitate place-making and change as opposed to the leadership merits of individual council leaders, chief executives or senior officers. The paper commences by exploring the concept of place poverty, and highlights the absence of any serious consideration of local leadership as a potential separate factor within the neighbourhood effects literature. Evidence on spatial variations in place-making outcomes across single tier local authorities in England is then presented. Having identified a range of factors that potentially determine the success or otherwise of local councils attempts at place-making, the paper then examines the extent to which local leadership and strategic vision within local councils exerts a significant independent impact upon levels of belonging, inclusion, and participation in 
local decision-making amongst local residents. Finally, the paper draws conclusions upon the importance of local leadership as an independent neighbourhood effect in relation to the realisation of the place-shaping agenda.

\section{Place Poverty, Neighbourhood Effects and the Neglect of Local Leadership}

The idea that 'place' has the potential to shape the quality of life within specific localities has been a constant theme within the literature concerning the geography of social problems (e.g. McCormick \& Philo, 1995; Shelton et al, 2006; Dorling et al, 2007). This literature has also sought to establish the concept of 'place poverty' as an additional approach to explaining and understanding the presence of social problems (i.e. "People are poor because where they live compounds the advantages or disadvantages of particular groups by virtue of where they live" [Smith, 1977:112]). In seeking to explain the spatial distribution of social inequalities, numerous authors have pointed to the existence of neighbourhood effects as an explanatory factor (e.g. Jencks \& Meyer, 1990; Atkinson \& Kintrea, 2001; Curtis et al, 2004). The physical, structural, social, economic and cultural characteristics and dynamics bound up within neighbourhoods thus provide an alternative perspective on social problems to those rooted in individual characteristics, circumstances and lifestyle choices (i.e. people poverty). Neighbourhood based explanations of social inequalities have, however, tended to be dominated by studies that focus upon (a) urban form and hierarchies (e.g. Park et al, 1925; Hoyt, 1939; Hall et al, 2001); (b) the physical and built environment (e.g. Jeffery, 1969, Schneider \& Kitchen, 2002); (c) the interaction between individuals and physical/social spaces (e.g. Jacobs, 1961; Newman, 1973; Coleman, 1985); and (d) levels of social cohesion/capital within different neighbourhoods (e.g. Forrest \& Kearns, 2001; Bridge, 2002).

An equally important determinant of life chances is the quality of local services, and the strategic ability of local public service agencies to tackle social problems and transform places (Buck, 2001; Galster, 2001). Whilst the spatial relationship between the social problems and the quantity of local services has received notable attention (e.g. Boyne \& Powell, 1991; Boyne \& Powell, 1993), variations in the quality of local services and local leadership as a separate neighbourhood effect has received little conceptual or empirical attention. Studies of spatial variations in local public service provision have primarily sought to explain the presence of such geographical differences in outputs and outcomes (e.g. Alt, 1971; Danziger, 1978; Sharpe \& Newton, 1984) rather than posit them as an independent determinant of social outcomes within different localities. Equally, conceptions of places within official classifications of localities (e.g. ONS Neighbourhood Classification, Home Office CDRP Crime Families) are centred upon social-demography and the scale of social problems (e.g. low life expectancy, unemployment, crime, housing conditions and affordability) rather than utilising the quantity/quality of local public services as an important factor in the conceptualisation of, and differentiation between, places. This omission is despite consistent official evidence of significant spatial variations across England in the relative performance of local councils (Audit Commission, 2009), and empirical evidence demonstrating that including the 
quality of public service provision in neighbourhood classifications shakes up conventional conceptions of 'poor' and 'thriving' localities (Hunter, 2010). It is in this context that this paper examines the impact of performance, leadership and strategic vision across single tier local authorities in England upon the realisation of the place-shaping agenda.

\section{Empirical Analysis}

\section{Spatial Variations in Place-Making Outcomes}

Accepting that individual choices about where to live are at best often constrained, our conceptions of 'ideal' places are both diverse and contested. Attempts throughout time to create model communities (e.g. planned communities [Bournville, Saltaire, Port Sunlight], the Garden City Movement, New Towns, or Eco Towns) reveal a diversity of ideas in relation to idealised forms of physical environment, infrastructure, socio-economic characteristics and outcomes, social organisation, ownership, freedom, and citizen participation. Furthermore in terms of individual connections with places, 'neighbourhood' can be defined in terms of territory (Davies and Herbert, 1993), common sense limits (Morris and Hess, 1975), symbolism (Keller, 1968), social relationships (Downs, 1981), shared public spaces (Schoenberg, 1979), or internally/externally recognised and enforced boundaries (Healey, 1998). Whilst contemporary evidence points to the importance of equality in achieving a more desirable society (e.g. Wilkinson \& Pickett, 2010), the recent policy emphasis upon social exclusion, social capital and sustainable communities suggests that place-making is as much about a sense of inclusion, belonging and fostering a connection between individuals and places, as it is about the achievement of specific socio-economic outcomes. The 'participative and proactive' citizen has been a common feature both in New Labour's form of communitarianism and the Coalition Government's emphasis on the Big Society (Blair, 1995; Cabinet Office, 2010). But the attainment of an engaged citizenry which is active in community affairs and public life cannot be realised if individuals feel no sense of belonging or connection with their neighbourhood. Whilst material circumstances, quality of life, opportunities and neighbourhood belonging are clearly intertwined with one another the relationship between these factors is not an automatic one.

The empirical analysis on place-making presented here draws upon a number of headline indicators relating to quality of life, belonging and identity, inclusion and participation present within the 2008 Place Survey (DCLG, 2009b). This survey across local authority areas in England sought local residents' opinions concerning their neighbourhood, what aspects of place ensure a good quality of life, and the contribution of public service organisations to the realisation of desirable place-making outcomes. Table One (overleaf) presents evidence on spatial variations in place-making outcomes across single tier local authority areas broken down by local authority type across England in 2008. 
Table One: Indicators of Place-Making Outcomes across English Local Authority Areas, 2008

\begin{tabular}{|c|c|c|c|c|c|}
\hline Indicator: & LA type: & Minimum & Maximum & Mean & $\begin{array}{l}\text { STD } \\
\text { DEV }\end{array}$ \\
\hline $\begin{array}{l}\text { \% who are satisfied with their } \\
\text { local area as a place to live } \\
\text { (SATISFIED) }\end{array}$ & $\begin{array}{l}\text { LB }(n=32) \\
\operatorname{MD}(n=36) \\
\text { UA }(n=45)\end{array}$ & $\begin{array}{l}\text { 56.0 Newham } \\
\text { 62.2 Sandwell } \\
\text { 63.6 Slough }\end{array}$ & $\begin{array}{l}\text { 92.1 Richmond upon Thames } \\
\text { 87.7 Solihull } \\
\text { 91.6 Rutland }\end{array}$ & $\begin{array}{l}74.8 \\
74.7 \\
78.6\end{array}$ & $\begin{array}{l}8.6 \\
5.8 \\
6.8\end{array}$ \\
\hline $\begin{array}{l}\text { \% who fell they belong to their } \\
\text { immediate neighbourhood } \\
\text { (BELONG) }\end{array}$ & $\begin{array}{l}\text { LB } \\
\text { MD } \\
\text { UA }\end{array}$ & $\begin{array}{l}\text { 42.8 Tower Hamlets } \\
\text { 47.6 Manchester } \\
\text { 44.4 Reading }\end{array}$ & $\begin{array}{l}\text { 64.1 Richmond upon Thames } \\
\text { 64.6 Sunderland } \\
\text { 68.0 East Riding of Yorkshire }\end{array}$ & $\begin{array}{l}52.0 \\
57.7 \\
56.0\end{array}$ & $\begin{array}{l}4.5 \\
4.1 \\
5.3\end{array}$ \\
\hline $\begin{array}{l}\text { \% who agree that their local area } \\
\text { is a place where people from } \\
\text { different backgrounds get on well } \\
\text { together (COHESION) }\end{array}$ & $\begin{array}{l}\text { LB } \\
\text { MD } \\
\text { UA }\end{array}$ & $\begin{array}{l}\text { 49.1 Barking \& Dagenham } \\
\text { 50.4 Oldham } \\
\text { 54.3 Thurrock }\end{array}$ & $\begin{array}{l}\text { 87.6 Richmond upon Thames } \\
\text { 83.5 Trafford } \\
\text { 86.1 Brighton \& Hove }\end{array}$ & $\begin{array}{l}75.8 \\
70.8 \\
75.0\end{array}$ & $\begin{array}{l}7.0 \\
6.8 \\
6.4\end{array}$ \\
\hline $\begin{array}{l}\text { \% who have been involved in } \\
\text { decisions that affect the local area } \\
\text { in the past } 12 \text { months } \\
\text { (INVOLVED) }\end{array}$ & $\begin{array}{l}\text { LB } \\
\text { MD } \\
\text { UA }\end{array}$ & $\begin{array}{l}\text { 11.3 Havering } \\
\text { 8.2 Sunderland } \\
\text { 7.9 Stockton on Tees }\end{array}$ & $\begin{array}{l}\text { 24.1 Camden } \\
\text { 16.5 Oldham } \\
\text { 21.1 Rutland }\end{array}$ & $\begin{array}{l}17.0 \\
11.9 \\
13.1\end{array}$ & $\begin{array}{l}3.2 \\
2.1 \\
2.6\end{array}$ \\
\hline $\begin{array}{l}\% \text { who agree that they can } \\
\text { influence decisions in their local } \\
\text { area (INFLUENCE) }\end{array}$ & $\begin{array}{l}\text { LB } \\
\text { MD } \\
\text { UA }\end{array}$ & $\begin{array}{l}\text { 24.8 Havering } \\
\text { 22.1 Doncaster } \\
\text { 20.9 Redcar \& Cleveland }\end{array}$ & $\begin{array}{l}\text { 45.7 Newham } \\
\text { 34.0 Manchester } \\
\text { 35.5 Luton }\end{array}$ & $\begin{array}{l}35.0 \\
27.2 \\
28.0\end{array}$ & $\begin{array}{l}4.6 \\
3.2 \\
3.4\end{array}$ \\
\hline
\end{tabular}

$\mathrm{LB}=$ London Boroughs, $\mathrm{MD}=$ Metropolitan Districts, UA=Unitary Authorities

Source: Place Survey 2008(DCLG, 2009b)

The results show a considerable level of variation in the scores for each place-making indicator across single tier authorities in England as evidenced by the minimum, maximum and standard deviation scores. This echoes the significant difference in mean scores for these indicators when broken down across the nine English regions [DCLG, 2009b]). Mean levels of satisfaction (SATISFIED) and tolerance of people from different backgrounds (COHESION) show noticeably higher scores than for levels of involvement and influence in relation to local decision making. There is some evidence of high place-making outcomes being registered in relation to more affluent areas - but this only remains consistent across all local authority types in relation to levels of satisfaction with localities as places to live. The London Boroughs appear to be performing more effectively in terms of engaging local citizens in decision making (INVOLVED and INFLUENCE). Having established the presence of spatial differences in place making outcomes, what are the factors that might explain these variations, and how important is local leadership and strategic vision in fostering a sense of place and identity?

\section{The Role of Local Leadership in Explaining Spatial Variations in Place Making Outcomes}

\section{Model and hypotheses}

The range of political, economic, environmental and socio-demographic factors that have significantly determined local service expenditures and outputs (see Boyne, 1996) are likely to prove equally influential in shaping levels of belonging, cohesion, and opportunities for participative decision-making within different localities. The degree of homogeneity amongst local residents in respect of age, social class and ethnicity is highly likely to impact upon the extent to which different elements within local populations will develop an attachment to neighbourhoods, show respect to different cultures and values, and take advantage of opportunities to engage with local service providers and decision-makers (Reidpath, 2003). More diverse populations will exhibit a greater range of social needs and expectations, making higher levels of satisfaction and belonging to localities harder to achieve. However, in respect of participation in decision-making, greater 
opportunities to become involved in local decision-making may materialise in more fragmented localities. The diverse urban/rural character of localities, which encapsulates both differing physical/socio-demographic characteristics and levels of deprivation, is also likely to demarcate urban neighbourhoods which experience continual population turnover, social diversity, and deprivation from rural areas that are often characterised by high levels of prosperity, social stability and levels of social capital (Hofferth \& Iceland, 1998). Local economic circumstances, opportunities and levels of deprivation are also likely to mitigate the level of successful placeshaping that occurs within different localities. Prosperous local economies which are the product of economic diversity, sustainable growth, proximity to markets, and hence the ability to attract new employers and labour are likely to be characterised by populations whose more positive attachment to localities is the product of household prosperity and genuine choice over whether to remain or exit. In contrast, local areas that are blighted with economic problems and social deprivation, and where the necessary structural economic change is harder to engineer, will see entrenched socio-economic deprivation diminish a desire amongst local residents to positively identify with localities and engage with local service providers and institutions.

Local authorities can exert their own influence on place-making outcomes in a number of respects. The importance of local leadership and strategic vision has already been alluded to within this paper. The performance of local councils in relation not only to service provision, but also in relation to community engagement and the fostering of participation in decision-making should also operate as an important catalyst for enhancing quality of life (and hence local connection) in the most holistic sense of the term. Additionally, responses to social deprivation and exclusion through higher levels of service provision should mitigate against the negative impact of social inequalities upon levels of engagement and belonging. Finally, the political disposition of local councils should realise different approaches to place-making. Developing an effective measure of political disposition is however highly problematic in respect of capturing ideological dispositions, competition and strategic alliances (Boyne, 1985). Furthermore, a range of local socio-economic, political, cultural and historical factors will ensure that ruling parties of the same political ilk will approach place-making differently within different parts of England. However, it is possible to suggest that Liberal Democrat and Labour administrations will, in ideological terms, broadly favour higher levels of service provision and state intervention to engineer positive place-shaping outcomes. In addition, Liberal ideology has conventionally witnessed a much higher commitment to grass roots democracy and community participation. In contrast, Conservative administrations are likely to be characterised by lower levels of taxation and service provision, and a much greater reliance upon market forces to transform localities into sustainable communities.

On the basis of the issues raised above, the following hypotheses have been generated to underpin the evaluation of the impact of local leadership upon place-making outcomes:

- Hypothesis One: Population diversity is negatively related to higher levels of belonging and cohesion - but positively related to participation in local decision-making. 
- Hypothesis Two: Rurality is positively related to higher levels of belonging, cohesion and participation.

- Hypothesis Three: Economic prosperity is positively related to higher levels of belonging, cohesion and participation.

- Hypothesis Four: Deprivation is negatively related to higher levels of belonging, cohesion and participation.

- Hypothesis Five: Local council performance is positively related to place-shaping.

- Hypothesis Six: A higher level of service provision is positively related to higher levels of belonging, cohesion and participation.

- Hypothesis Seven: Centre-left and Left political ideology is positively related to promoting cohesion and participation.

\section{Variables and data sources}

In order to test the independent impact of local leadership and strategic vision upon spatial variations in place-making in 2008 (see Table One above), ten independent measures that encapsulate aspects of the local socio-economic and political environment identified in the hypotheses above have been included in the multivariate analysis. It is also necessary to build in a time delay into the analysis in relation to political control, local leadership, and levels of service provision in order to enable the impact of previous decisions to filter through into the time period in which place-making outcomes are being assessed. In order to capture the socio-demographic character of different localities, a modified version of the Hehrfindahl index approach employed by Andrews et al (2005) has been employed. This index separately measures the scale of population fragmentation in relation to age, ethnicity and social class diversity (all 2001). The sum of the squared proportion across specific categories (e.g. age band, ethnicity, socio-economic occupation) is subtracted from a value of 10,000 in order to arrive at an index of fragmentation (with a higher degree of fragmentation being represented by a higher value on the index). Social and economic deprivation is measured using the overall rank of deprivation (from the Index of Multiple Deprivation 2007), change in the proportion of the working population who are registered as unemployed (averaged between 2000-2008), and changes in total criminal offences per thousand population (between 2002/3-2007/8). The urban/rural character of localities is included using the DEFRA classification of local authorities (2005) which is based upon the size and distribution of populations across different types of urban and rural settlements. Quantity of service provision is measured using data on total expenditure per capita (averaged between 2000-2004), whilst the performance of local councils is based upon the proportion of the local population who are satisfied with the overall efforts of their local authority (in 2008). Political disposition of localities is measured using the nature of political control by specific parties (in 2004). The impact of individual leadership from council leaders, chief executives or community leaders often plays a vital role in place-shaping, but capturing this in a valid and reliable quantitative form is methodologically problematic. The Comprehensive Performance Assessment measures of local authority corporate performance derived from the designated key lines of enquiry set out by the Audit Commission have therefore been deployed to measure the quality of local leadership and strategic vision across 
local authority areas in England (in 2002/3). This form of corporate assessment scores local councils in terms of aspects of strategic vision and performance that directly map onto the placemaking leadership attributes identified within the Lyons review of local government (Lyons Inquiry into Local Government, 2007).

Table Two (below) identifies the descriptive statistics and data sources for the eleven independent variables included within the multivariate analysis. Prior to the multivariate analysis, tests were conducted for the distribution of the dependent and independent variables to establish the absence of skewed data which proved to be the case for all variables. The results for the multivariate analysis using OLS regression also satisfied the requirements for assumptions concerning homoscedasticity in relation to the interpretation of the regression coefficients.

Table Two: Descriptive statistics $(n=113)$

\begin{tabular}{|c|c|c|c|}
\hline & Minimum & Maximum & Mean \\
\hline $\begin{array}{l}\text { Rank of deprivation (1=highest } \\
\text { deprivation) }\end{array}$ & $\begin{array}{l}1 \\
\text { (Liverpool) }\end{array}$ & $\begin{array}{l}353 \\
\text { (Wokingham) }\end{array}$ & 102.9 \\
\hline Change in unemployment (\%) & $\begin{array}{l}-30.2 \\
\text { (Southwark) }\end{array}$ & $\begin{array}{l}193.0 \\
\text { (Rotherham) }\end{array}$ & 56.3 \\
\hline Change in crime (\%) & $\begin{array}{l}-42.7 \\
\text { (Camden) }\end{array}$ & $\begin{array}{l}16.1 \\
\text { (Southampton) }\end{array}$ & -20.0 \\
\hline Age diversity & $\begin{array}{l}7254.3 \\
\text { (Wandsworth) }\end{array}$ & $\begin{array}{l}8004.3 \\
\text { (Bournemouth) }\end{array}$ & 7792.3 \\
\hline Ethnic diversity & $\begin{array}{l}179 \\
\text { (Herefordshire) }\end{array}$ & $\begin{array}{l}7902.4 \\
\text { (Newham) }\end{array}$ & 2195.5 \\
\hline Class diversity & $\begin{array}{l}8771.6 \\
\text { (Richmond upon Thames) }\end{array}$ & $\begin{array}{l}9484.5 \\
\text { (Liverpool) }\end{array}$ & 9183.6 \\
\hline Urban/rural classification & (Multiple) & (Multiple) & 1.92 \\
\hline Total expenditure per capita $(£)$ & $\begin{array}{l}990.6 \\
\text { (York) }\end{array}$ & $\begin{array}{l}2308.9 \\
\text { (Tower Hamlets) }\end{array}$ & 1324.1 \\
\hline $\begin{array}{l}\text { Satisfaction with how council } \\
\text { runs things }(\%)\end{array}$ & $\begin{array}{l}22.4 \\
\text { (Rotherham) }\end{array}$ & $\begin{array}{l}72.7 \\
\text { (Croydon) }\end{array}$ & 44.3 \\
\hline $\begin{array}{l}\text { Local leadership and strategic } \\
\text { vision }\end{array}$ & $\begin{array}{l}5 \\
\text { (North Tyneside) }\end{array}$ & 20 & 13.6 \\
\hline Political control of local council & (Multiple) & (Multiple) & 3.5 \\
\hline
\end{tabular}

Data sources:

Deprivation - - Index of Multiple Deprivation 2007 (Department for Communities and Local Government)

Unemployment - NOMIS Labour Market Profiles (www.nomis.org.uk)

Crime - Crime in England and Wales 2002/3 to 2007/8 (Home Office)

Age Diversity - Census 2001: Six age categories: 0-15, 16-24, 25-44, 45-64, 65-84, 85+ (ONS, www.neighbourhood.statistics.gov.uk)

Ethnic Diversity - Census 2001: Nine categories: White, Mixed, Indian, Pakistani, Chinese, Black African, Black Caribbean, Chinese, Other (ONS, www.neighbourhood.statistics.gov.uk)

Class Diversity - - Census 2001: National Statistics Socio-Economic Classifications, 12 categories: Large employers and high managerial occupations higher professional occupations, lower managerial and professional occupations, intermediate occupations, small employers and own account workers, lower supervisory and technical occupations, semi-routine occupations, routine occupations, never worked, long-term unemployed, full-time students, non-classifiable (ONS, www.neighbourhood.statistics.gov.uk)

Urban/rural Total expenditure - DEFRA Urban/Rural Classification of Local Authorities in England, 2005 (www.defra.gov.uk)

- Place Survey, 2008. London: Audit Commission

local council

Local leadership - Comprehensive Performance Assessment for single tier authorities (Audit Commission)

Political control

- Municipal Year Book. London: Local Government Chronicle

\section{Multivariate analysis results}

Multiple regression results relating to the overall explanatory power of the model, and the separate impact of the independent variables upon each dependent measure of place-making are presented 
in Table Three overleaf. Results are only provided in relation to models and standardised regression coefficients that are significant at the $95 \%$ level. Tests revealed an acceptable level of multicolinearity across the independent variables (VIF $<=10$ [Miller et al, 2002]). In relation to all of the dependent measures of place-making, the explanatory power of the model (Adjusted $R^{2}$ ) is significant. However the level of explanation provided by the model is much higher for ability to influence local decisions (INFLUENCE, 78\%) and satisfaction of local people with the local area as a place to live (SATISFIED, 65\%) when compared to people from different backgrounds getting on well (COHESION, 38\%) and sense of belonging to locality (BELONG, 40\%).

\section{Table Three: Multivariate results for alternative measures of place-making - Single tier councils in England, 2008}

Overall explanatory power of model:

\begin{tabular}{|l|l|l|l|l|l|}
\hline Dependent variable: & SATISFIED & BELONG & COHESION & INVOLVED & INFLUENCE \\
\hline $\mathrm{N}$ & 113 & 113 & 113 & 113 & 113 \\
\hline Adj R & .65 & .44 & .38 & .50 & .78 \\
\hline Sig. & $* * *$ & $* * *$ & $* * *$ & $* * *$ & $* * *$ \\
\hline
\end{tabular}

Standardised regression coefficients:

\begin{tabular}{|l|c|c|c|c|c|}
\hline Independent variable: & $\mathrm{B}$ & $\mathrm{b}$ & $\mathrm{b}$ & $\mathrm{B}$ & $\mathrm{B}$ \\
\hline Rank of deprivation & $.32^{* *}$ & & $.35^{* *}$ & & \\
\hline Change in unemployment & & & & & \\
\hline Change in crime & $-.23^{* * *}$ & $-.28^{* * *}$ & & & \\
\hline Age diversity & & & & & $.64^{* * *}$ \\
\hline Ethnic diversity & $-.38^{* * *}$ & $-.57^{* * *}$ & & & $.26^{*}$ \\
\hline Class diversity & & & & & $.12^{*}$ \\
\hline Urban/rural classification & $.19^{*}$ & & & $.21^{*}$ & $.48^{* * *}$ \\
\hline Total expenditure per capita & & & $-.29^{*}$ & $.46^{* * *}$ & \\
\hline Satisfaction with how council runs things & $.32^{* * *}$ & & & & $-.13^{*}$ \\
\hline Local leadership and strategic vision & & & $.41^{* * *}$ & & $.22^{*}$ \\
\hline Political control of local council & $-.16^{*}$ & & & & \\
\hline
\end{tabular}

Significance levels: $*=95 \%, * *=99 \%, * * *=99.9 \%$

The results for the standardised regression coefficients reveal mixed support for the hypotheses articulated above. The evidence reveals that change in levels of unemployment, and the diversity of the population in respect of age, exert no significant influence with respect to any of the dependent measures of place-making. Diversity in respect of social class is only significant in relation to ability to influence local decision-making (but realises the expected impact). Reduced levels of deprivation, and changes in crime, both result in higher levels of satisfaction with the local area - and respectively produce the expected improvements in a sense of cohesion and belonging. A shift from large urban to more rural localities produces positive improvements in levels of satisfaction, and involvement/influence in relation to local decision-making.

With respect to the various characteristics and activities of local councils, the evidence in relation to place-making is mixed. Political control only exerts a significant influence on levels of satisfaction and being involved in local decision-making. The negative impact upon satisfaction amongst residents resulting from a shift towards pro-spending administrations may reflect the higher possibility of more deprived populations who demand higher levels of service provision 
returning Labour controlled councils. This explanation is mirrored in relation to higher levels of total expenditure producing significantly lower levels of cohesion. Political control in the form of pro-spending, and higher levels of expenditure, also show a significant positive relationship with levels of involvement in decision-making. This may be the result of both an ideological commitment to citizen participation and greater levels of expectation concerning involvement amongst local residents where levels of service provision are higher. Satisfaction with how the local council runs things unsurprisingly results in higher levels of satisfaction amongst residents and a stronger belief that they can influence local decision-making. There is little evidence however that local leadership and strategic vision exerts a consistently significant impact across all aspects of place-making. Increases in levels of the performance of local councils in relation to local leadership and strategic vision only result in improved levels of cohesion, but decreasing belief amongst local residents in relation to their ability to influence local decision-making. These results may respectively reflect the harder efforts of local councils to bring populations from different backgrounds together, but also a tendency for the need for greater consultation with local citizens as well as other local stakeholders in driving forward a strategic vision for the local area.

\section{Conclusion}

This paper set out to explore the importance of local leadership and the strategic vision of local councils in shaping places and improving the quality of life experienced by individuals living within different localities in England. The narrative identified the importance attached to local leadership within contemporary discourses on place-making, and established the potential for the lack of leadership and strategic vision to exert a separate and significant negative impact upon the socioeconomic outcomes of, and opportunities for, individuals and communities. The evidence presented within the paper, however, provides little support for the belief that local leadership matters when it comes to shaping places and transforming satisfaction, belonging and participation amongst local residents. This result points perhaps to the ephemeral nature of both local leadership and the forces that shape the opinions of people in relation to place. Perceptions concerning localities are often quickly established, rooted in unknown causes - and once entrenched are hard to change.

The importance of achieving policy success in transforming localities and achieving sustainable communities will assume even more importance in a time of fiscal austerity. The Coalition Government's localism agenda is designed to strengthen the role of local government by freeing up local councils from central government control, and enhancing the participation of local communities in decision-making. This raises the potential for local leadership to assume a new level of importance in juggling scarce resources whilst engineering new forms of local governance in policy-making and service delivery. Few would question the conceptual policy link between effective local leadership and successful place-making, or the potential for variations in the quality of services, organisational performance and local leadership to continue to exert an independent neighbourhood effect within different communities. We do however need to move to a position 
where the official classification and designation of place becomes more conceptually and methodologically sophisticated - and embraces public sector supply side as well as socio-economic demand side factors in evaluating the nature of localities, and the factors which shape the quality of life within these places. Only then will we start to arrive at a position in which we can develop an enriched and extensive understanding of place-making and the catalysts that bring about the sustainable transformation of neighbourhoods.

\section{References}

Alt, J. (1971), Some social and political correlates of County Borough expenditures. British Journal of Political Science, 1, pp. 49-62.

Andrews, R. et al (2005), External constraints on local service standards: The case of the Comprehensive Performance Assessment in English local government', Public Administration, 83:3, pp. 639-656;

Atkinson, R. \& Kintrea, K. (2001), Disentangling area effects: Evidence from deprived and non-deprived neighbourhoods. Urban Studies, 38, 12, pp. 2277-2298.

Audit Commission (2003), Community Leadership: Learning from Comprehensive Performance Assessment Briefing 1 (London, Audit Commission).

Audit Commission (2009), Final Score: The Impact of Comprehensive Performance Assessment of Local Government 2002-08 (London, Audit Commission).

Barber, A. \& Eastaway, M. (2010), Leadership challenges in the inner city: planning for sustainable regeneration in Birmingham and Barcelona. Policy Studies Journal, 31, 4, pp. 393-411.

Blair, T. (1995), The rights we enjoy reflect the duties we owe, The Spectator Lecture (London, Labour Party).

Boyne, G. (1985), Theory, methodology and results in political science: The case of output studies", British Journal of Political Science, 15, 4, pp. 473-515

Boyne, G. (1996), Constraints, Choices and Public Policies (London, JAI Press).

Boyne, G \& Powell, M. (1991), Territorial justice: A review of theory and evidence. Political Geography Quarterly, 10, 3, pp. 263-281.

Boyne, G \& Powell, M. (1993), Territorial justice and Thatcherism. Environment \& Planning C: Government and Policy, 11, 1, pp. 35-53.

Bridge, G. (2002), The Neighbourhood and Social Networks (Bristol/Glasgow, ESRC Centre for Neighbourhood Research, CNR Paper No. 4.)

Buck, N. (2001), Identifying neighbourhood effects on social exclusion. Urban Studies, 38, 12, pp. 2251-2275.

Cabinet Office (2010), Building the Big Society (London, Cabinet Office).

Coleman, A. (1985), Utopia on Trial: Vision and Reality in Planned Housing (London, Hilary Shipman).

Collinge, C. \& Gibney, J. (2010), Place-making and the limitations of spatial leadership: Reflections on the Øresund. Policy Studies Journal, 31, 4, pp. 475-489.

Curtis, S. et al (2004), Area effects on health variation over the life-course: Analysis of the Longitudinal Study Sample in England using new data on area of residence in childhood. Social Science \& Medicine, 58, pp. 5774.

Danziger, J. (1978), Making Budgets (London, Sage). 
Davies, W. \& Herbert, D. (1993), Communities within Cities: An Urban Social Geography (London, Belhaven Press).

Department for Communities and Local Government (DCLG), (2006), Stronger and Prosperous Communities: The Local Government White Paper (London, The Stationary Office).

Department for Communities and Local Government (2008a), Place Matters: The Location Strategy for the United Kingdom (London, The Stationary Office).

Department for Communities and Local Government (2008b), Communities in Control: Real People, Real Power (London, The Stationary Office).

Department for Communities and Local Government (2009a), Empowering Communities to Influence Local Decision-Making: Evidence-based Lessons for Policy Makers and Practitioners London, DCLG.

Department for Communities and Local Government (2009b), Place Survey 2008, England - Headline Results (see www.communities.gov.uk/documents/statistics/pdf/1326142.pdf).

Department for Transport, Local Government and the Regions (2001), Strong Local Leadership - Quality Public Services. (London, The Stationary Office).

Dorling, D. et al (2007), Poverty, Wealth and Place in Britain, 1968 to 2005 (Bristol, Policy Press).

Downs, A. (1981), Neighbourhoods and Urban Development (Washington DC, Brookings Institution).

Forrest, R. \& Kearns, A. (2001), Social cohesion, social capital and the neighbourhood. Urban Studies, 38, 12, pp. 2125-2143.

Galster, G. (2001), On the nature of neighbourhood. Urban Studies, 3, 12, pp. 2111-2124.

Hall, P. et al (2001), The changing urban hierarchy in England and Wales, 1913-1998. Urban Studies, 35, 9, pp. 775-807.

Healey, P. (1998), Institutional theory, social exclusion and governance, in A. Madanipour et al. (eds.) Social Exclusion in the Cities. (London, Jessica Kingsley Publishers).

HM Treasury/Department for Communities and Local Government (2010), Total Place: A Whole Area Approach to Public Services (London, The Stationary Office).

Hofferth, S. \& Iceland, J. (1998), Social capital in urban and rural communities. Rural Sociology, 63, 4, pp. 574-598.

Hoyt, H. (1939), The Structure and Growth of Residential Neighbourhoods in American Cities (Washington DC, US Government Printing Office).

Hunter, J. (2010), Place, neighbourhood and health, in A. Barnard (ed.) A Reader in Health and Social Care (London, Routledge).

Jacobs, J. (1961), The Death and Life of Great American Cities (New York, Vintage Books).

Jeffery, C. (1969), Crime prevention and control through environmental engineering. Criminologica, 7, pp. 3558.

Jencks, C. \& Mayer, S. (1990), The social consequences of growing up in a poor neighbourhood, in L. Luynn \& M. McGeary (eds.) Inner City Poverty In The United States (Washington DC, National Academy Press).

Keller, S. (1968), The Urban Neighbourhood: A Sociological Perspective (New York, Random House).

Lyons, M. (2007), Lyons Inquiry into Local Government. Place-shaping: A Shared Ambition for the Future of Local Government (London, The Stationary Office).

McCormick, J \& Philo, C. (1995), Where is poverty? The hidden geography of poverty in the United Kingdom, in C. Philo (ed.), Off the Map: The Social Geography of Poverty in the UK (London, Child Poverty Action Group).

Miller, R. et al (2002), SPSS for Social Scientists (Basingstoke: Palgrave Macmillan).

Morris, D. \& Hess, K. (1975), Neighbourhood Power (Boston, MA, Beacon Press). 
Mullins D and van Bortel, G. (2010), Neighbourhood regeneration and place leadership: Lessons from Groningen and Birmingham. Policy Studies, 31, pp. 413-428.

Newman, O. (1973), Defensible Space: People and Design in the Violent City (London, Architectural Press).

Office of the Deputy Prime Minister (2003), Sustainable Communities: Building for the Future (London, OPDM).

Park, R., E. Burgess and R. McKenzie (1925), The City (Chicago, University of Chicago Press);

Reidpath, D. (2003), Love thy neighbour - it's good for your health: A study of racial homogeneity, mortality and social cohesion in the United States. Social Science \& Medicine, 57, 2, pp. 253-261.

Schneider, R. \& Kitchen, T. (2002), Planning for Crime Prevention: A Transatlantic Perspective (London, Routledge).

Schoenberg, S. (1979), Criteria for the evaluation of neighbourhood viability in working class and low incomes areas in core cities. Social Problems, 27, pp. 69-85.

Sharpe, L. \& Newton, K. (1984), Does Politics Matter? The Determinants of Public Policy (Oxford, Clarendon Press).

Shelton, N. et al (2006), Where not to live: A geo-demographic classification of mortality for England and Wales, 1981-2000. Health \& Place, 12, pp. 557-569.

Smith, D. (1977), Human Geography: A Welfare Approach (London, Edward Arnold).

Social Exclusion Unit (2001), A New Commitment to Neighbourhood Renewal: National Strategy Action Plan (London, The Stationary Office).

Stoker, G. (2004), Transforming Local Governance: From Thatcherism to New Labour (Basingstoke, Palgrave).

Sweeting, D. et al (2004), Leadership and partnership in urban Governance: Evidence from London, Bristol and Glasgow, in M. Boddy \& M. Parkinson (eds.) City Matters. Competitiveness, Cohesion and Urban Governance (Bristol, Policy Press).

Wilkinson, R. \& Pickett, K. (2010), The Spirit Level: Why Equality is Better for Everyone (London, Penguin). 